\title{
Nutrient optimization for production of polyhydroxybutyrate from halotolerant photosynthetic bacteria cultivated under aerobic-dark condition
}

\author{
Kanokphorn Sangkharak \\ Department of Industrial Biotechnology \\ Faculty of Agro-Industry \\ Prince of Songkla University \\ Hatyai, Thailand P.O. Box 90112 \\ Tel: 6674286363 \\ Fax: 6674212889 \\ E-mail: skanokphorn@yahoo.com \\ Poonsuk Prasertsan* \\ Department of Industrial Biotechnology \\ Faculty of Agro-Industry \\ Prince of Songkla University \\ Hatyai, Thailand P.O. Box 90112 \\ Tel: 6674286369 \\ Fax: 6674212889 \\ E-mail: poonsuk918@yahoo.com
}

Financial support: This work was supported by Thailand Research Fund (TRF) under Royal Golden Jubilee (RGJ)-Ph.D Program.

Keywords: aerobic-dark cultivation, optimization, PHB, polyhydroxybutyrate, Rhodobacter sphaeroides.

Abbreviations: DCW: dry cell weight

GC-MS: gas chromatography-mass spectrometry

GM: glutamate-malate

NTG: N-methly-N'-nitro-N-nitrosoguanidine

PHAs: polyhydroxyalkanoates

PHB: polyhydroxybutyrate

TEM: transmission electron microscopy

UV: ultraviolet

Three halotolerant bacterial strains; Rhodobacter sphaeroides ES16 (the wild type) and the two mutant strains of $R$. sphaeroides ES16, namely N20 and U7, were cultivated in glutamate-malate (GM) medium and screened for production of polyhydroxybutyrate (PHB). The mutant strains $\mathrm{N} 20$ and $\mathrm{U} 7$ were found to accumulate PHB (53.9 and $42.0 \%$ of DCW, respectively) 3.6 and 2.8 times higher than the wild type strain $(19.5 \%$ of DCW), respectively. $R$. sphaeroides N20 were selected for studies on the effects of nutrient and environmental conditions on PHB accumulation. The optimal condition was $4 \mathrm{~g} / \mathrm{l}$ acetate, $0.02 \mathrm{~g} / \mathrm{l}\left(\mathrm{NH}_{4}\right)_{2} \mathrm{SO}_{4}$, $\mathrm{C} / \mathrm{N}$ ratio of 6:1, $1.0 \mathrm{~g} / \mathrm{l} \mathrm{K}_{2} \mathrm{HPO}_{4}, 1.0 \mathrm{~g} / \mathrm{KH}_{2} \mathrm{PO}_{4}$ and $3 \% \mathrm{NaCl}$ with initial $\mathrm{pH}$ at 7.0. Under this optimal condition, the maximum PHB accumulation increased from $53.9 \%$ to $88 \%$ of $\mathrm{DCW}$ and $9.11 \pm 0.08 \mathrm{~g} / \mathrm{l}$ biomass, $8.02 \pm 0.10$ g/l PHB concentration were achieved after $60 \mathrm{hrs}$ cultivation at $37^{\circ} \mathrm{C}$. These results are the highest values ever obtained from photosynthetic bacteria reported so far.

Polyhydroxyalkanoates (PHAs) are a class of natural polyesters, which can be produced and accumulated by many Gram-positive and Gram-negative bacteria from at least 75 different genera. These polymers are accumulated intracellularly under conditions of nutrient stress and act as a carbon and energy reserve (Steinbüchel, 2001; Reddy et al. 2003). PHB is the well known studied and best characterized PHAs. It is accumulated when carbon and energy sources are in excess, but growth is limited by the lack of oxygen, nitrogen, or phosphorus source. The characteristic of this compound is similar to synthetic plastic or petrochemical-based plastics (such as polypropylene, polyurethane, vinyl chloride and hexachloroethane etc.). Therefore, PHB and its copolymer can be used as biodegradable plastic, which can reduce the current problems with decreasing fossil resources and environmental impact caused by plastic garbage (Luengo et al. 2003). In addition, it has a promising application in medicine, material science and agriculture, etc. (He et al. 2004). However, the important factor preventing the industrial and commercial production of PHB is its high price of production as compare to synthetic plastic. Therefore, improved cultivation medium and conditions are

*Corresponding author 
required for reducing the cost (Khanna and Srivastava, 2004).

Halotolerant bacteria were reported to produce high amounts of PHAs (40-60\% DCW) were accumulated in halotolerant bacteria under the starvation condition (Hassan et al. 1997; Khatipov et al. 1998; Luengo et al. 2003; Chen et al. 2006). Recently, the highest PHAs production was obtained from $R$. sphaeroides strain $14 \mathrm{~F}$ which showed (3.5 $\mathrm{g} / 1$ PHA, 60\% DCW) cultivated in modified GM medium where malate was substituted by $5 \mathrm{~g} / 1$ fructose under twostage aerobic dark condition (Lorrungruang et al. 2006). Halotolerant photosynthetic bacteria have the advantage over the other microorganisms in their ability to adjust themselves to both presence and absence of photo as well as able to live in saline condition which offers a multitude of actual or potential applications in various fields of biotechnology (Morgesin and Schinner, 2001; Massadeh et al. 2005).

This investigation reports the occurrence of PHB in halotolerant photosynthetic bacteria isolated from marine natural resources in Thailand and investigation on optimization of PHB production by the selected strain.

\section{MATERIALS AND METHODS}

\section{Microorganisms, medium and growth conditions}

Three halotolerant PHB-producing photosynthetic bacteria used in this study were Rhodobacter sphaeroides ES 16 (the wild type) and the two mutants named N20 and U7 obtained from mutation of the strain ES16 by using Nmethyl-N'-nitro-N-nitrosoguanidine (NTG) and ultraviolet (UV), respectively. All strains were grown at $37^{\circ} \mathrm{C}$ in GM medium containing (g/l) L-glutamic acid 3.8, D,L-malate 2.7, yeast extract 2.0, $\mathrm{KH}_{2} \mathrm{PO}_{4} 0.5, \mathrm{~K}_{2} \mathrm{HPO}_{4} 0.5,\left(\mathrm{NH}_{4}\right)_{2} \mathrm{SO}_{4}$ $0.8, \mathrm{MgSO}_{4} .7 \mathrm{H}_{2} \mathrm{O} 0.2, \mathrm{CaCl}_{2} .2 \mathrm{H}_{2} \mathrm{O} 0.053, \mathrm{MnSO}_{4} .5 \mathrm{H}_{2} \mathrm{O}$ 0.0012 and basal medium (Lascelles, 1956) with the addition of $30 \mathrm{~g} / \mathrm{l} \mathrm{NaCl}$ (Tangprasittipap et al. 2007). Basal medium contained $(\mathrm{mg} / \mathrm{l})$ nicotinic acid 1.0, thiamine 1.0 and biotin 0.01 (Watanabe et al. 1981). The $\mathrm{pH}$ was adjusted to 7.0 .

These three have been kept in the Microbial Culture Collection and Microbiological Services of Thailand, Institute of Scientific and Technological Research (TISTR), Ministry of Science and Technology, Thailand. They were deposited as TISTR1526, TISTR1527 and TISTR1528, respectively.

\section{Selection of the highest PHB producing strain}

The three strains of halotolerant photosynthetic bacteria $R$. sphaeroides (ES16, N20 and U7) were cultivated in GM medium at $37^{\circ} \mathrm{C}$ for $96 \mathrm{hrs}$. Cells were harvested and analyzed for PHB by gas chromatography (GC) (Steinbüchel and Wiese, 1992). The samples were harvested from three shaken flasks and assayed in duplicate. The strain giving the highest amount of PHB was selected for studies on the effects of nutrient and environmental conditions.

\section{Effect of nutrient and environmental conditions}

Starter culture were prepared by inoculating the selected strain in $100 \mathrm{ml}$ GM medium and incubated on a shaker $(150 \mathrm{rpm})$ at $37^{\circ} \mathrm{C}$ for $48 \mathrm{hrs}$. The starter culture containing $1.5 \times 10^{4}$ viable cells $/ \mathrm{ml}$ was inoculated $(10 \%)$ to GM medium supplemented with various nutrients compositions by varying carbon sources and concentrations (glucose, fructose or acetate at 0-6 g/l), nitrogen sources and concentrations $\left(\left(\mathrm{NH}_{4}\right)_{2} \mathrm{SO}_{4}, \mathrm{NH}_{4} \mathrm{NO}_{3}\right.$ and $\mathrm{NH}_{4} \mathrm{Cl}$ at $0-0.2$ $\mathrm{g} / \mathrm{l})$, mineral salts $\left(\mathrm{KH}_{2} \mathrm{PO}_{4}, \mathrm{~K}_{2} \mathrm{HPO}_{4}, \mathrm{MgSO}_{4}, \mathrm{CaCl}_{2}\right.$ and $\mathrm{MnSO}_{4}$ at $0-1 \mathrm{~g} / \mathrm{l}$ ) and vitamin (nicotinic acid, raminobenzoic acid, thiamine each at $0-1 \mathrm{mg} / \mathrm{l}$, biotin at 0 $0.01 \mathrm{mg} / 1$ or no addition of vitamin). The cells were cultivated on a shaker $(150 \mathrm{rpm})$ at $37^{\circ} \mathrm{C}$ under aerobic-dark condition. Growth (in term of dried cell weight, DCW), $\mathrm{pH}$ and PHB content were determined at the end of cultivation (60 hrs).

\section{Time course study on PHB production}

Time course on PHB production from the selected strain under the optimal condition was studied. The experiments were conducted in a 3-1 glass fermentor with three six bladed Rushton turbine impellers (40 $\mathrm{mm}$ dia.) and equipped with $\mathrm{pH}$ controlled at 7; dissolved oxygen (DO), antifoam and temperature probes connected to the controller; and the agitation speed of $150 \mathrm{rpm}$. Samples were taken at time interval to determine for $\mathrm{pH}$, growth (DCW) and PHB content during $96 \mathrm{hrs}$ cultivation.

\section{Determination of cell concentration}

Total cell concentration was determined by weighing the dry cell mass obtained as follows. Ten $\mathrm{ml}$ culture samples were centrifuged at $13,000 \mathrm{rpm}(12,846 \mathrm{x} \mathrm{g})$ for $15 \mathrm{~min}$ at $4^{\circ} \mathrm{C}$. The pellet was resuspended in distilled water $(10 \mathrm{ml})$ and centrifuged again for washing. The washed cells were dried at $105^{\circ} \mathrm{C}$ for $24 \mathrm{hrs}$ in a hot air oven then cooled down in desiccators. The drying was repeated until constant weight was obtained (Grothe et al. 1999). The true cell concentration was determined by subtracting the PHB concentration from the total cell concentration (Jung et al. 2000).

\section{Determination of PHB content by gas chromatography (GC)}

For qualitative determination, PHB were analyzed in whole-cell samples or after extraction with chloroform and purification by repeated precipitation from a chloroform solution with ethanol. The PHB content and composition were determined by subjecting 5 to $8 \mathrm{mg}$ of lyophilized cells or 1 to $2 \mathrm{mg}$ of isolated $\mathrm{PHB}$, respectively, to methanolysis, which was done in a mixture of chloroform and methanol containing $15 \% \quad(\mathrm{v} / \mathrm{v})$ sulfuric acid (Steinbüchel and Wiese, 1992). The resulting hydroxyacyl 
Table 1. Comparison on cellular growth and PHB content from three strains of halotolerant photosynthetic bacteria after cultivation in $\mathrm{GM}$ medium ( $\mathrm{pH} 7.0)$ on a shaker $(150 \mathrm{rpm})$ at $37^{\circ} \mathrm{C}$ for $96 \mathrm{hrs}$.

\begin{tabular}{|c|c|c|c|c|}
\hline \multirow[b]{2}{*}{ Strain } & \multirow{2}{*}{$\underset{\left(\mathbf{h}^{-1}\right)}{\mu}$} & Maximum growth & \multicolumn{2}{|c|}{ PHB } \\
\hline & & $\begin{array}{c}\mathrm{DCW}^{\mathrm{a}} \\
(\mathrm{g} / \mathrm{l})\end{array}$ & $\begin{array}{c}\text { Conc. } \\
\text { (g/l) }\end{array}$ & $\begin{array}{l}\text { Content }{ }^{\mathrm{b}} \\
(\% \text { of DCW) }\end{array}$ \\
\hline R. sphaeroides ES16 & 0.021 & $7.44 \pm 0.20$ & $1.45 \pm 0.15$ & 19.5 \\
\hline R. sphaeroides N20 & 0.022 & $8.23 \pm 0.09$ & $4.44 \pm 0.23$ & 53.9 \\
\hline R. sphaeroides U7 & 0.022 & $8.12 \pm 0.11$ & $3.41 \pm 0.22$ & 42.0 \\
\hline
\end{tabular}

${ }^{\mathrm{a}} \mathrm{DCW}=$ Dry cell weight $=$ total cell concentration.

${ }^{\mathrm{b}} \mathrm{PHB}$ content $(\% \mathrm{DCW})=(\mathrm{PHB}$ concentration/DCW $) \times 100$.

methylesters were analyzed with gas chromatograph (Brandl et al. 1988; Timm et al. 1990). The initial structural assignments of the methylesters analyzed were based on their retention times compared to those of authentic standards. GC analysis was performed on a Hewlett Packard GC-1450 system equipped with an INNOWAX capillary column (length, $30 \mathrm{~m}$; internal diameter, $0.25 \mathrm{~mm}$; film thickness, $0.25 \mu \mathrm{m}$ ) and a flame ionization detector.

\section{Transmission electron microscopy (TEM)}

In brief, at the end of cultivation the cell were harvested and immediately fixed in Millonig's phosphate buffer supplemented with 3\% glutaraldehyde and incubated for several days at $4^{\circ} \mathrm{C}$. SEM samples were further fixed in $1 \%$ osmium tetroxide for $1 \mathrm{hr}$ at room temperature. The samples were then rinsed with Millonig's phosphate buffer and gradually dehydrated with ethanol (Jung et al. 2000).

For TEM, samples of the diaphragm and housing were infiltrated with resin and ethanol, embedded in the resin overnight, cut with a diamond knife to a thickness of $60-80$ $\mathrm{nm}$, pulse-stained in uranyl acetate and lead citrate, and finally viewed under a transmission electron microscope (Jung et al. 2000).

\section{RESULTS AND DISCUSSION}

\section{Selection of the highest PHB producing strain}

Three strains of halotolerant photosynthetic bacteria were screened for PHB production in GM medium using malate as a carbon source. Time-course analysis (Figure 1) indicated that PHB was a growth-associated product and its accumulation significantly increased when all cultures reached the exponential phase (after $18 \mathrm{hrs)} \mathrm{till} \mathrm{stationary}$ phase (about 48-60 hrs). The maximum values were achieved at $60 \mathrm{hrs}$ cultivation. After $60 \mathrm{hrs}$, a slight decrease in the level of DCW coincided with a small decrease in PHB content. This indicated that the presence of an intracellular PHB depolymerase and PHA concentration decreased significantly after $72 \mathrm{hrs}$ cultivation due to nutrient depletion and cells consumption of PHB as a carbon source. The lower total dry cell weight of the mutants corresponded with high amount of PHA production within $48 \mathrm{hrs}$ cultivation. These halotolerant bacteria produced PHB during exponential phase which was similar to Alcaligenes latus and substantially different from Ralstonia eutropha (recent name Cupriavidus eutropha), which accumulated PHB at the stationary phase (Madison and Huisman, 1999). In addition, Caulobacter crescentus DSM4727 accumulated PHB simultaneously with cell growth and reached its maximum level after approximately $60 \mathrm{hrs}$ (Qi and Rehm, 2001).

Among three halotolerant strains, R. sphaeroides N20 gave the highest values for PHB concentration $(4.44 \pm 0.23 \mathrm{~g} / \mathrm{l})$ and PHB content $(53.9 \%$ of $\mathrm{DCW})$, followed by $R$. sphaeroides U7 $(3.41 \pm 0.22 \mathrm{~g} / 1$ and $42.0 \%$ of DCW, respectively) (Table 1). $R$. sphaeroides ES16 (1.45 \pm 0.15 $\mathrm{g} / \mathrm{l}$ and $19.5 \%$ of DCW, respectively) accumulated PHB 2-3 folds lower than the two mutant strains. In contrast, their biomass obtained were not significantly difference $(8.23 \pm$ $0.09 \mathrm{~g} / 1,8.12 \pm 0.11 \mathrm{~g} / \mathrm{l}$ and $7.44 \pm 0.20 \mathrm{~g} / \mathrm{l}$, respectively) as well as the specific growth rate (0.021-0.022). During cultivation, the $\mathrm{pH}$ values increased from $\mathrm{pH} 7.00$ to alkaline value of 8.25 at $60 \mathrm{hrs}$ cultivation although this did not affect other parameters at the end of the cultivation. PHB production from $R$. sphaeroides N20 $(4.44 \pm 0.23 \mathrm{~g} / \mathrm{l}$ and $53.9 \%$ ) was higher than the other halotolerant bacteria R. sphaeroides IFO 12203 (4 g/l PHA and 67\% of DCW) under anaerobic light condition after $200 \mathrm{hrs}$ cultivation (Hasan et al. 1997) and $0.5 \mathrm{~g} / 1$ PHA production from waste water of refined sugar using R. sphaeroides O.U. 001 (Yigit et al. 1999). The PHA content was within the range of 50$90 \%$ of DCW produced by commercial PHA producing bacteria such as Cupriavidus eutropha or recombinant $E$. coli (Steinbüchel, 2001). It was interesting to note that the strain N20 produced the highest PHA concentration (4.44 \pm 
$0.23 \mathrm{~g} / 1$ and $53.9 \%$ of DCW) ever reported for $R$. sphaeroides (3.5 g/l with 60\% PHA content) (Lorrungruang et al. 2006).

Transmission electron microscopic photographs of $R$. sphaeroides ES16, N20 and U7 in GM medium after $72 \mathrm{hrs}$ are illustrated (Figure 2). All bacterial strains contained one or more PHB granules. The size distribution of PHB granules ranged from 0.5 to $1.0 \mu \mathrm{m}$ with the mean value of $0.5 \pm 0.06 \mu \mathrm{m}$. While the cells of $R$. sphaeroides ES16 contained only one or two PHB granules, the mutants $R$. sphaeroides N20 and U7 contained white huge inclusion bodies in the cytoplasmic fluid of bacteria and the cells were elongated and inflationary depend on the number of granules inside. The mutant N20 contained larger amount of granules than the mutant U7 which supported the higher content of PHB in the cells. From the data described above, $R$. sphaeroides N20 was selected for optimization studies.

\section{Effect of nutrients on PHB production}

Carbon source and concentration. Effect of various carbon sources and concentrations on growth and PHB production from $R$. sphaeroides N20 in GM medium were studied where malate was substituted by glucose, fructose or acetate at 0-6 g/l (Figure 3). The strain assimilated all the carbon sources tested and gave the maximum cell growth $(8.95 \pm 0.17 \mathrm{~g} / \mathrm{l})$ and PHB production $(6.53 \pm 0.10 \mathrm{~g} / \mathrm{l}$ and $72.9 \%$ of DCW) after $60 \mathrm{hrs}$ cultivation in the medium using $4 \mathrm{~g} / 1$ acetate as a carbon source. In GM medium with glucose and fructose as carbon sources, growth reached the peak values at $4 \mathrm{~g} / 1$ concentration as well $(7.9 \pm 0.14$ and $7.89 \pm 0.21 \mathrm{~g} \mathrm{DCW} / 1$, respectively) with PHB concentration of $4.83 \pm 0.12$ and $4.50 \pm 0.09 \mathrm{~g} / \mathrm{l}$, respectively and $\mathrm{PHB}$ content of 61 and $57 \%$ of DCW, respectively. Without any tested carbon source, growth was lowest because bacteria used glutamate both as carbon and nitrogen sources. The results indicated that the optimal concentration of c-source was $4 \mathrm{~g} / 1$ in all three carbon sources tested. Glucose, fructose and acetate were good substrates for both cellular growth and polyester formation compared with results using their combination. The combined of these three carbon sources at final concentration of $4 \mathrm{~g} / 1$ promoted cell growth (7-8 g/l), but gave low values for PHB formation (2-3 g/l). Changes of $\mathrm{pH}$ during the cultivation in various carbon sources and concentrations were in the range of 8-9.

The above results indicated that acetate was the best carbon source for PHB production by $R$. sphaeroides N20. The modified GM medium replacing D, L malate with $4 \mathrm{~g} / 1$ (48 $\mathrm{mM}$ ) of acetate was named glutamate-acetate (GA) medium. This result was agreed with the data from $R$. sphaeroides RV using acetate $(40 \mathrm{mM})$ as a carbon source which gave the highest PHB content (up to $40 \%$ of DCW) compared with the alternative carbon sources such as lactate, pyruvate and glucose under nitrogen-deprived conditions (Khatipov et al. 1998). Replacement of malate with acetate which was commercially available and $10 \%$ cheaper than malate was one of the advantages for production of PHB at large scale. In addition, $R$. sphaeroides was reported to utilize a wide range of substrates under dark or photo-fermentation at relatively high temperature $\left(35 \pm 2^{\circ} \mathrm{C}\right)$ (Lorrungruang et al. 2006) leading to more diversified substrates and applications.

Nitrogen source and concentration. Effect of various nitrogen sources and concentrations on the cellular growth and PHB production from $R$. sphaeroides N20 cultivating in GA medium were investigated. Results indicated that at higher concentrations of all nitrogen sources tested $(0.08$, 0.1 and $0.2 \mathrm{~g} / \mathrm{l}$ ), both cell growth (5.74-7.84 g/l) and PHB concentration (0.95-2.07 $\mathrm{g} / \mathrm{l})$ increased significantly but PHB content decreased (Figure 4). In contrast, at low nitrogen concentrations (0.01, 0.02 and $0.04 \mathrm{~g} / \mathrm{l})$, PHB content reached $24-73 \%$ of DCW. The optimal nitrogen source and concentration was $0.02 \mathrm{~g} / 1\left(\mathrm{NH}_{4}\right)_{2} \mathrm{SO}_{4}$, giving the highest PHB concentration $(5.98 \pm 0.11 \mathrm{~g} / \mathrm{l})$ and $\mathrm{PHB}$ content $(73.2 \%$ of DCW) as well as biomass $(8.19 \pm 0.23$

Table 2. The effect of $\mathrm{C} / \mathrm{N}$ ratio on PHB accumulation by Rhodobacter sphaeroides $\mathrm{N} 20$ after 60 hrs cultivation in GA medium containing acetate, $\left(\mathrm{NH}_{4}\right)_{2} \mathrm{SO}_{4}$ as carbon and nitrogen source, respectively at $37^{\circ} \mathrm{C}, 150 \mathrm{rpm}, \mathrm{pH} 7.0$.

\begin{tabular}{|c|c|c|c|}
\hline \multirow{2}{*}{$\begin{array}{c}\text { C/N ratio } \\
\text { (mole of C/mole of N) }\end{array}$} & Maximum growth & \multicolumn{2}{|c|}{ PHB } \\
\cline { 2 - 4 } & $\begin{array}{c}\text { DCW } \\
\text { (g/l) }\end{array}$ & $\begin{array}{c}\text { Conc. } \\
\text { (g/l) }\end{array}$ & $\begin{array}{c}\text { content } \\
\text { (\% of DCW) }\end{array}$ \\
\hline $12: 1$ & $7.80 \pm 0.09$ & $3.67 \pm 0.22$ & 47.0 \\
\hline $6: 1$ & $8.11 \pm 0.12$ & $5.94 \pm 0.11$ & 73.2 \\
\hline $3: 1$ & $6.63 \pm 0.15$ & $1.85 \pm 0.14$ & 27.9 \\
\hline $0.3: 1$ & $5.98 \pm 0.21$ & $0.75 \pm 0.19$ & 12.6 \\
\hline $0.15: 1$ & $5.44 \pm 0.10$ & $0.36 \pm 0.08$ & 6.7 \\
\hline
\end{tabular}


$\mathrm{g} / \mathrm{l})$. It was reported that accumulation of PHB in photosynthetic bacteria is normally associated with nitrogen availability in the growth medium more specific such as the optimum $\mathrm{C} / \mathrm{N}$ ratio (Khatipov et al. 1998). $\left(\mathrm{NH}_{4}\right)_{2} \mathrm{SO}_{4}$ was optimal nitrogen source for PHA production compared to $\mathrm{NH}_{4} \mathrm{NO}_{3}, \mathrm{NH}_{4} \mathrm{Cl}$ as well as urea in other microorganisms such as Alcaligenes eutrophus (recent name Cupriavidus eutropha) (Grothe et al. 1999; Koutinas et al. 2007), Methylobacterium sp. (Kim et al. 2006) and Sinorhizobium fredii (Liangqi et al. 2006). Forty times lower amount of $\left(\mathrm{NH}_{4}\right)_{2} \mathrm{SO}_{4}$ (from 0.8 to $0.02 \mathrm{~g} / \mathrm{l}$ ) in the optimum medium could tremendously reduce the medium cost, hence, gave higher potential for large scale production of PHB.

Nutrient limitation is necessary to trigger PHB accumulation, and generally ammonia is used as the critical control factor for uncoupling the growth of cells and PHB production (Wang and Lee, 1997). A recombinant E. coli strain gave the maximum PHB content (about 60\% PHB of $\mathrm{DCW})$ at a specific combination of yeast extract and peptone (Mahishi et al. 2003). Similar results were obtained from cultivation of Anaerobiospirillum succiniproducens and Phaffia rhodozyma in the presence of yeast extract, and a combination of yeast extract and peptone (Kusdiyantini et al. 1998; Lee et al. 2000).

Carbon to nitrogen ratio (C/N ratio). $R$. sphaeroides $\mathrm{N} 20$ was cultivated in the culture medium with $4 \mathrm{~g} / \mathrm{l}$ acetate and $0.02 \mathrm{~g} / 1\left(\mathrm{NH}_{4}\right)_{2} \mathrm{SO}_{4}$ as a carbon and nitrogen source, respectively. The $\mathrm{C} / \mathrm{N}$ ratios were varied at $12: 1,6: 1,3: 1$, 0.3:1 and 0.15:1 (mole C/mole N) (Table 2). The optimum $\mathrm{C} / \mathrm{N}$ ratio was found to be $6: 1$ in which $R$. sphaeroides $\mathrm{N} 20$ possessed the highest PHB content of $73.2 \%$ of DCW and $5.94 \pm 0.11 \mathrm{~g} / \mathrm{l}$ PHB concentration. This confirmed the previous section results (Nitrogen source and concentration). Too high $(12: 1)$ and low $(<6: 1)$ C:N ratio caused significant decline of PHB concentration (0.36-3.67 $\mathrm{g} / \mathrm{l})$ and PHB content (6.7-47.0\% of DCW) in the cells.

Type and concentration of mineral salts. $R$. sphaeroides N20 was cultivated in the culture medium with the optimal $\mathrm{C} / \mathrm{N}$ ratio (6:1). Effect of different mineral salts such as $\mathrm{KH}_{2} \mathrm{PO}_{4}, \mathrm{~K}_{2} \mathrm{HPO}_{4}, \mathrm{MgSO}_{4}, \mathrm{CaCl}_{2}$ and $\mathrm{MnSO}_{4}$ at the concentrations of $0,0.01,0.1$ and $1 \mathrm{~g} / 1$ were studied. Use of $\mathrm{KH}_{2} \mathrm{PO}_{4}$ lower than $0.1 \mathrm{~g} / 1$ caused reduced cellular growth (7.04-7.67 g/l) and PHB production (3.87 $\pm 0.01 \mathrm{~g}$ PHB/l) (Figure 5a). The $\mathrm{pH}$ in cultures increased to almost 10 within less than 1 day. In contrast, $\mathrm{KH}_{2} \mathrm{PO}_{4}$ concentration of $\geq 0.1 \mathrm{~g} / \mathrm{l}$ gave higher values (5.04-6.57 $\mathrm{g} \mathrm{PHB} / \mathrm{l})$ and similar result was obtained with $\mathrm{K}_{2} \mathrm{HPO}_{4}$. At $0.1 \mathrm{~g} / 1$ $\mathrm{K}_{2} \mathrm{HPO}_{4}$, the best values were obtained $(8.73 \pm 0.11 \mathrm{~g} / \mathrm{l}$ and $6.42 \pm 0.20$ as well as $73.6 \%$ of PHB content) (Figure $5 b$ ). It was reported that $R$. sphaeroides consumed all the acetate $(10 \mathrm{mM})$ but hardly used any glutamate when cultivated in un-buffered medium (Hustede et al. 1993). Phosphate limiting condition (in presence of $\mathrm{KH}_{2} \mathrm{PO}_{4}$ and $\mathrm{K}_{2} \mathrm{HPO}_{4}$ ) was important factor for PHB production. However, addition of phosphate was also required for cell growth and loss of buffer capacity led to high $\mathrm{pH}$ of approximately 10 -
11 which might be growth inhibiting level. It was reported that PHB accumulation in Nostoc muscorum increased to $22.7 \%$ of DCW after 4 days of phosphate deficiency whereas PHB content in S. platensis remained low even after prolonged phosphate starvation (Panda et al. 2006).

For the effect of other mineral salts; $\mathrm{CaCl}_{2}, \mathrm{MgSO}_{4}$ and $\mathrm{MnSO}_{4}(0-1 \mathrm{~g} / \mathrm{l})$ had no effect either on cellular growth (8.01-8.92 g/l), PHB concentration (5.76-6.15 g/l) as well as PHB content (69.0-70.9\% of DCW). The PHB content was not significant different between cultivation of the strain N20 in control GA medium $(70.1 \%$ of DCW) and medium with no addition of $\mathrm{CaCl}_{2}, \mathrm{MgSO}_{4}$ and $\mathrm{MnSO}_{4}$ $(69 \%$ of DCW). The results agreed with those of Nikel et al. 2005, who reported that $\mathrm{MgSO}_{4} \cdot 7 \mathrm{H}_{2} \mathrm{O}$ concentrations (1$10 \mathrm{mM}$ ), trace elements solution $(1-20 \mathrm{ml} / \mathrm{l})$, and inoculum size (0.01-10 g DCW/l) did not affect PHB production in mineral medium. Therefore, $0.1 \mathrm{~g} / 1 \mathrm{KH}_{2} \mathrm{PO}_{4}$ and $0.1 \mathrm{~g} / \mathrm{l}$ $\mathrm{K}_{2} \mathrm{HPO}_{4}$ were found to be the optimal mineral salts for maximum PHB production from $R$. sphaeroides N20.

Effect of vitamin on PHB production. Effect of different vitamins such as nicotinic acid $(0-1 \mathrm{mg} / \mathrm{l}), \mathrm{r}$-aminobenzoic acid $(0-1 \mathrm{mg} / \mathrm{l})$, thiamine $(0-1 \mathrm{mg} / \mathrm{l})$ and biotin $(0-0.01$ $\mathrm{mg} / \mathrm{l}$ ) or no addition of vitamin on growth and PHB production from $R$. sphaeroides $\mathrm{N} 20$ cultivated in the optimum medium was studied. It was found that vitamin had the least effect on cellular growth (7.98-8.40 g/l) and no effect on PHB concentration and content (5.87-6.10 g/1 and $72.1-73.6 \%$ of DCW). Therefore, $R$. sphaeroides N20 showed the ability to grow and accumulate PHB in the medium without any vitamin which can reduce $20-30 \%$ of medium cost and consequently lower the production cost. It was reported that high cost of PHB making their applications limited (Lakshmar et al. 2004; Khanna and Srivastava, 2004). $R$. sphaeroides N20 demonstrated the potential for PHB production in an industrial scale.

Time course on PHB production under optimal condition. $R$. sphaeroides $\mathrm{N} 20$ was cultivated in the optimal medium, $\mathrm{pH}$ controlled at 7.0 , incubation at $37^{\circ} \mathrm{C}$ for $96 \mathrm{hrs}$. The cultivation was performed in a 3-1 fermentor with aeration rate of $1.0 \mathrm{vvm}$ and agitation speed of 150 rpm. The results (Figure 6) indicated that the cellular growth was $9.11 \pm 0.08 \mathrm{~g} / 1$ and the PHB values from using the optimum medium were about two times higher than those using the GM medium with the productivity of 0.133 $\mathrm{g} / \mathrm{lh}$. PHB concentration was $8.02 \pm 0.10 \mathrm{~g} / \mathrm{l}$ and PHB content was $88 \%$ DCW.

\section{CONCLUDING REMARKS}

The objectives of this study were to develop fermentation process for a high production of PHB by selecting the prominent PHB accumulating bacteria and optimization studies. Among 3 strains of the halotolerant photosynthetic bacteria, $R$. sphaeroides $\mathrm{N} 20$ gave the highest value of specific growth rate $(\mu)\left(0.022 \mathrm{~h}^{-1}\right)$, PHB production $(4.44 \pm$ $0.23 \mathrm{~g} / \mathrm{l})$ as well as PHB content (53.9\% of DCW) in GM 
medium. The optimum medium for $R$. sphaeroides $\mathrm{N} 20$ consisted of $4 \mathrm{~g} / 1$ acetate, $0.02 \mathrm{~g} / 1\left(\mathrm{NH}_{4}\right)_{2} \mathrm{SO}_{4}, 6: 1 \mathrm{C} / \mathrm{N}$ ratio, $0.1 \mathrm{~g} / \mathrm{l}$ each of $\mathrm{K}_{2} \mathrm{HPO}_{4}$ and $\mathrm{KH}_{2} \mathrm{PO}_{4}$, without supplementation of any mineral salts and vitamin. The highest PHB production obtained was $8.02 \pm 0.10 \mathrm{~g} / \mathrm{l}$ and $88 \%$ of DCW. The above results indicated that this strain accumulated high amount of PHB using cheap medium.

\section{REFERENCES}

BRANDL, H.; GROSS, R.A.; LENZ, R.W. and FULLER, R.C. Pseudomonas oleovorans as a source of poly $(\beta-$ hydroxyalkanoates) for potential applications as biodegradable polyesters. Applied and Environmental Microbiology, August 1988, vol. 54, no. 8, p. 1977-1982.

CHEN, D.; HAN, Y. and GU, Z. Application of statistical methodology to the optimization of fermentative medium for carotenoids by Rhodobacter sphaeroides. Process Biochemistry, 2006, vol. 41, no. 8, p. 1773-1778.

GROTHE, E.; YOUNG, M.M. and CHISTI, Y. Fermentation optimization for the production of $\operatorname{poly}(\beta-$ hydroxybutyric acid) microbial thermoplastic. Enzyme and Microbial Technology, 1999, vol. 25, no.1-2, p. 132-141.

HASSAN, A.M.; SHIRAI, Y.; KUSUBAYASHI, N.; ISMAIL ABDUL KARIM, M.; NAKANISHI, K. and HASHIMOTO, K. The production of polyhydroxyalkanoate from anaerobically palm oil mill effluent by Rhodobacter sphaeroides. Journal of Fermentation and Bioengineering, 1997, vol. 83, no. 5, p. 485-488.

HE, G.Q.; KONG, Q. and DING, L.X. Response surface methodology for optimization the fermentation medium of Clostridium butyricum. Letters in Applied Microbiology, 2004, vol. 39, no. 4, p. 363-368.

HUSTEDE, E.; STEINBÜCHEL, A. and SCHEGAL, H.G. Relationship between the photoproduction of hydrogen and the accumulation of PHB in non-sulphur purple bacteria. Applied Microbiology and Biotechnology, 1993, vol. 39, no. 1, p. 87-93.

JUNG, Y.M.; PARK, J.S. and LEE, Y.H. Metabolic engineering of Alcaligenes eutrophus through the transformation of cloned $p h b C A B$ genes for the investigation of the regulatory mechanism of polyhydroxyalkanoate biosynthesis. Enzyme and Microbial Technology, February 2000, vol. 26, no. 2, p. 201-208.

KHANNA, S. and SRIVASTAVA, A.K. Recent advances in microbial polyhydroxyalkanoates. Process Biochemistry, 2004, vol. 40, no. 2, p. 607-619.

KHATIPOV, E.; MIYAKEA, M.; MIYAKEC, J. and ASADAA, Y. Accumulation of poly- $\beta$ hydroxybutyrate by Rhodobacter sphaeroides on various carbon and nitrogen substrates. FEMS Microbiology Letters, 1998, vol. 162, no. 1, p. 39-45.

KIM, M.; BAEK, J. and LEE, J.K. Comparison of $\mathrm{H}_{2}$ accumulation by Rhodobacter sphaeroides KD131 and its uptake hydrogenase and PHB synthase deficient mutant. International Journal of Hydrogen Energy, 2006, vol. 31, no. 1, p. 121-127.

KOUTINAS, A.A.; XU, Y.; WANG, R. and WEBB, C. Polyhydroxybutyrate production from a novel feedstock derived from a wheat-based biorefinery. Enzyme and Microbial Technology, April 2007, vol. 40, no. 5, p. 10351044.

KUSDIYANTINI, E.; GAUDIN, P.; GOMA, G. and BLANC, P.J. Growth kinetics and astaxanthin production of Phaffia rhodozyma on glycerol as a carbon source during batch fermentation. Biotechnology Letters, October 1998, vol. 20, no. 10, p. 929-934.

LAKSHMAR, K.; RASTOGI N.K. and SHAMALA, T.R. Simultaneous and comparative assessment of parent and mutant strain of Rhizobium meliloti for nutrient limitation and enhance polyhydroxyalkanoate (PHA) production using optimization studies. Process Biochemistry, 2004, vol. 39, no. 12, p. 1977-1983.

LASCELLES, J. The synthesis of porphyrins and bacteriochlorophyll by cell suspensions of Rhodobacter sphaeroides. Biochemical Journal, January 1956, vol. 62, no. 1, p. 7893.

LEE, S.Y.; CHOI, J. and LEE, S.H. Production of polyhydroxyalkanoates by fermentation of bacteria. Macromolecular Symposia, 2000, vol. 159, no. 1, p. 259266.

LIANGQI, Z.; JINGFAN, X.; TAO, F. and HAIBIN, W. Synthesis of poly (3 hydroxybutyrate co-3hydroxyoctanoate) by a Sinorhizobium fredii strain. Letters in Applied Microbiology, 2006, vol. 4, p. 344-349.

LORRUNGRUANG, C.; MARTTHONG, J.; SASAKI, K. and NOPARATNARAPORN, N. Selection of photosynthetic bacterium Rhodobacter sphaeroides 14F for polyhydroxyalkanoate production with two-stage aerobic dark cultivation.Journal of Bioscience and Bioengineering, 2006, vol. 101, no. 2, p. 128-131.

LUENGO, J.M.; GARCIA, B.; SANDOVAL, A.; NAHARRO, G. and OLIVER, E.R. Bioplastics from microorganisms. Current Opinion in Biotechnology, 2003, vol. 6, p. 251-260.

MADISON, L.L. and HUISMAN, G.W. Metabolic engineering of poly(3 hydroxyalkanoates): from DNA to plastic. Microbiology and Molecular Biology Review, March 1999, vol. 63, no. 1, p. 21-53. 
MAHISHI, L.H.; TRIPATHI, G. and RAWAL, S.K. Poly(3-hydroxybutyrate) (PHB) synthesis by recombinant Escherichia coli harbouring Streptomyces aureofaciens PHB biosynthesis genes: Effect of various carbon and nitrogen sources Microbiological Research, 2003, vol. 158, no. 1, p. $19-27$.

MASSADEH, A.M.; AL-MOMANI, F.A. and HADDAD, H.I. Removal of lead and cadmium by halophilic bacteria isolated from the Dead Sea shore, Jordan. Trace Element Research, December 2005, vol. 108, no. 1-3, p. 259-269.

MORGESIN, R. and SCHINNER, F. Potential of halotolerant and halophilic microorganisms for biotechnology. Extremophiles, April 2001, vol. 5, no. 2, 7383.

NIKEL, P.I.; PETTINARI, M.J.; MENDEZ, B.S. and GALVAGNO, M.A. Statistical optimization of a culture medium for biomass and poly(3-hydroxybutyrate) production by recombinant Escherichia coli strain using agroindustrial by products. International Microbiology, 2005 , vol. 8, p. 243-250.

PANDA, B.; JAIN, P.; SHARMA, L. and MALLICK, N. Optimization of cultural and nutritional conditions for accumulation of poly- $\beta$-hydroxybutyrate in Synechocystis sp. PCC 6803. Bioresource Technology, 2006, vol. 97, no. 11, p. 1296-1301.

QI, Q. and REHM, B.H.A. Polyhydroxybutyrate biosynthesis by Caulobacter crescentus: physiology and molecular characterization of the polyhydroxybutyrate synthase. Microbiology, 2001, vol. 147, p. 3353-3358.

REDDY, C.S.K.; GHAI, R.; RASHMI and KALAI, V.C. Polyhydroxyalkanoates: an overview. Bioresource Technology, April 2003, vol. 87, no. 2, p. 137-146.

STEINBÜCHEL, A. and WIESE, S. A Pseudomonas strain accumulating polyesters of 3-hydroxybutyric acid and medium-chain-length 3-hydroxyalkanoic acids. Applied Microbiology and Biotechnology, 1992, vol. 37, no. 6, p. 691-697.

STEINBÜCHEL, A. Perspectives for biotechnological production and utilization of biopolymers: metabolic engineering of polyhydroxyalkanoate biosynthesis pathways as a successful example. Macromolecule Bioscience, February 2001, vol. 1, no. 1, p. 1-24.

TANGPRASITTIPAP, A.; PRASERTSAN, P.; CHOORIT, $\mathrm{W}$. and SASAKI,K. Biosynthesis of intracellular 5aminolevulinic acid from newly identified Halotolerant Rhodobacter sphaeroides SH5. Biotechnology Letters, May 2007, vol. 29, no. 5, p. 773-778.

TIMM, A.; BYROM, D. and STEINBÜCHEL, A. Formation of blends of various poly(3 hydroxyalkanoic acids) by a recombinant strain of Pseudomonas oleovorans.
Applied Microbiology and Biotechnology, 1990, vol. 33, no. 3, p. 296-301.

WANG, F. and LEE, S.Y. Poly(3-Hydroxybutyrate) production with high productivity and high polymer content by a fed-batch culture of Alcaligenes latus under nitrogen limitation. Applied and Environmental Microbiology, 1997, vol. 63, no. 9, p. 3703-3706.

WATANABE, K.; KIM, J.S.; ITO, K.; BURANAKRAL, L.; KAMPEE, T. and TAKAHASHI, H. Thermostable nature of hydrogen production by non-sulfur purple photosynthetic bacteria isolated in Thailand. Agricultural and Biological Chemistry, 1981, vol. 45, no. 1, p. 217-222.

YIGIT, D.O.; GUNDUZ, U.; TURKER, I.; YUCEL, M. and EROGLU, I. Identification of by-products in hydrogen producing bacteria: Rhodobacter sphaeroides O.U. 001 grown in the waste water of sugar refinery. Journal of Biotechnology, 1999, vol. 70, no. 1-3, p. 125-131. 


\section{APPENDIX \\ FIGURES}

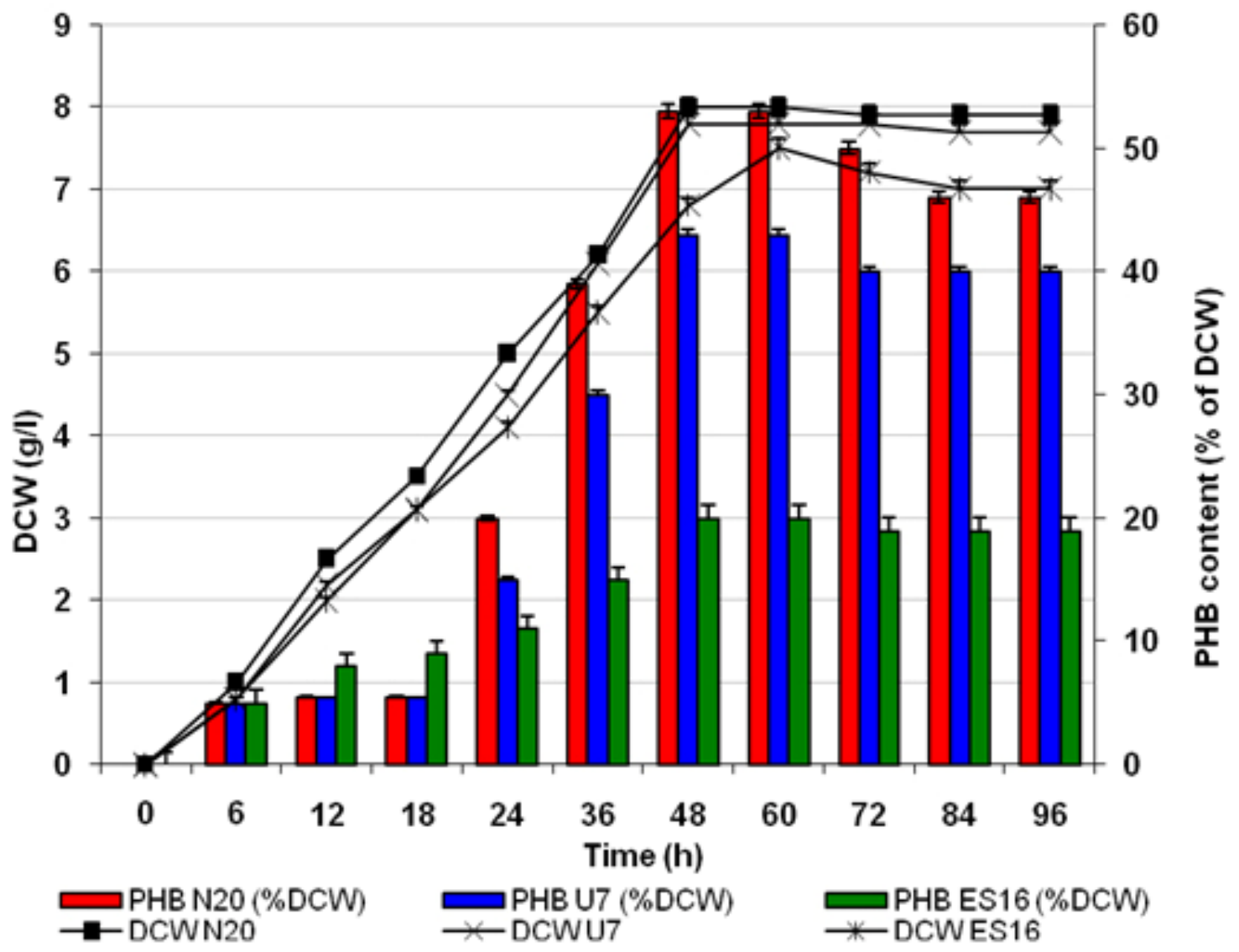

Figure 1. PHB accumulations from three halotolerant bacterial strains. Cells were cultivated in $\mathrm{GM}$ medium at $\mathrm{pH} 7.0,37^{\circ} \mathrm{C}, 150 \mathrm{rpm}$ for 96 hrs.
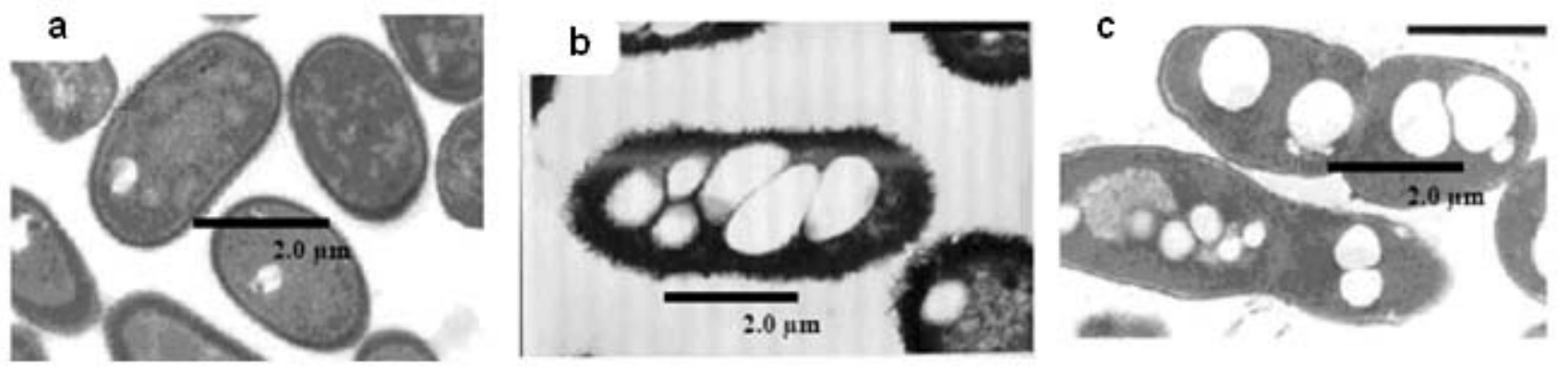

Figure 2. Transmission electron microscopic photographs of (a) $R$. sphaeroides ES16; (b) $R$. sphaeroides N20; and (c) $R$. sphaeroides U7 in GM medium containing malate as a carbon source at the stationary phase (72 hrs). Bacterial cells packed with poly- $\beta$-hydroxybutyrate inclusion bodies. Bar $=2.0 \mu \mathrm{m}$. 

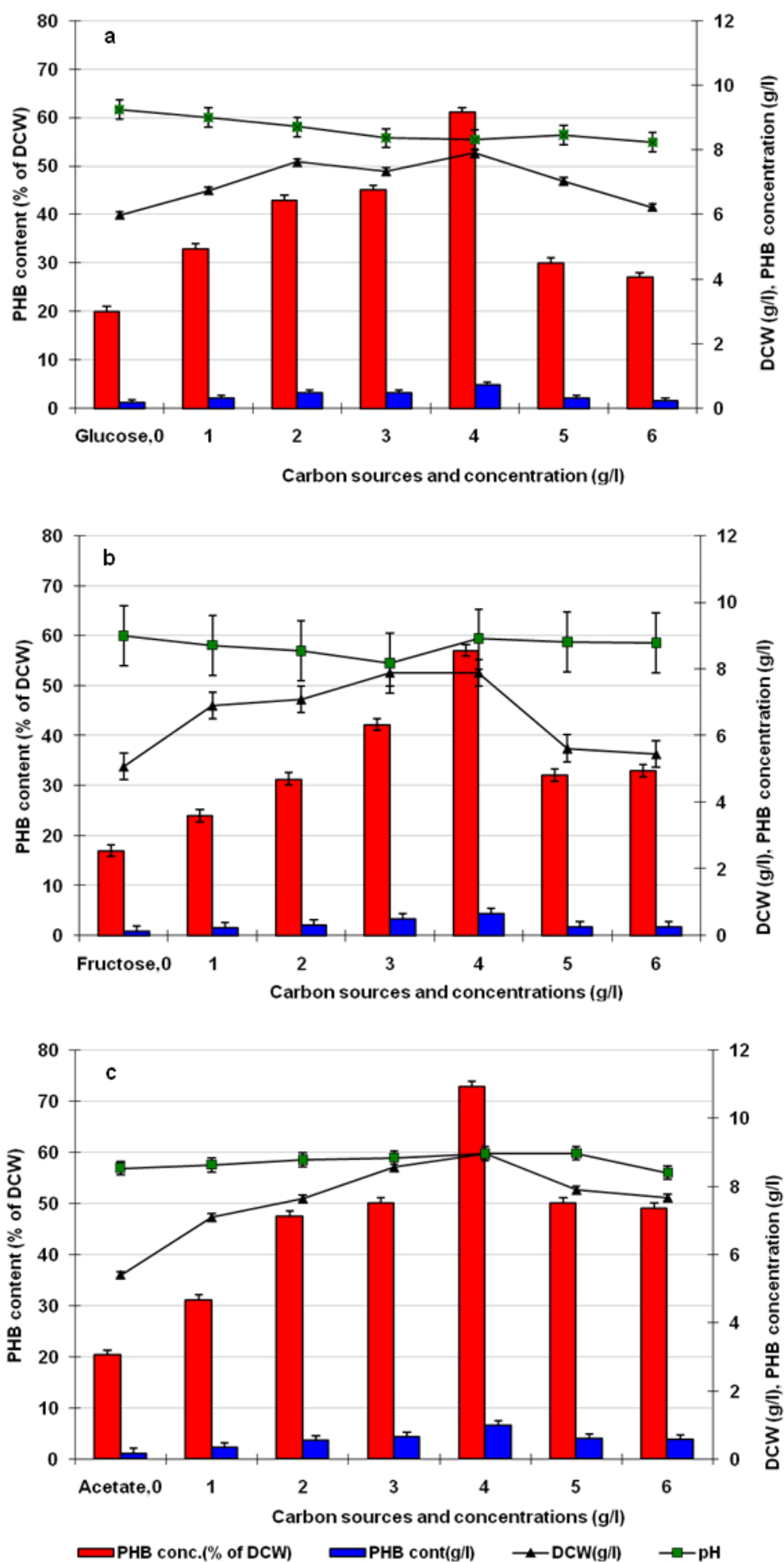

Figure 3. Growth and PHB accumulation during cultivation of $R$. sphaeroides N20 in GM medium with (a) glucose; (b) fructose; and (c) acetate at various concentrations (0-6 g/l) under aerobic-dark condition at $37^{\circ} \mathrm{C}$ on shaker $(150 \mathrm{rpm})$. Cell harvested at 60 hrs. 


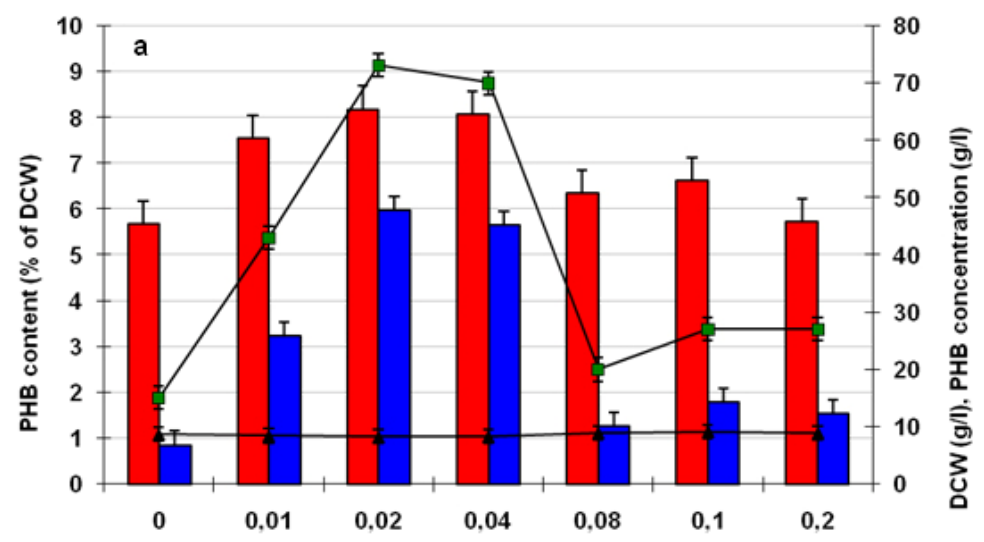

Nitrogen sources and concentrations (g/l)

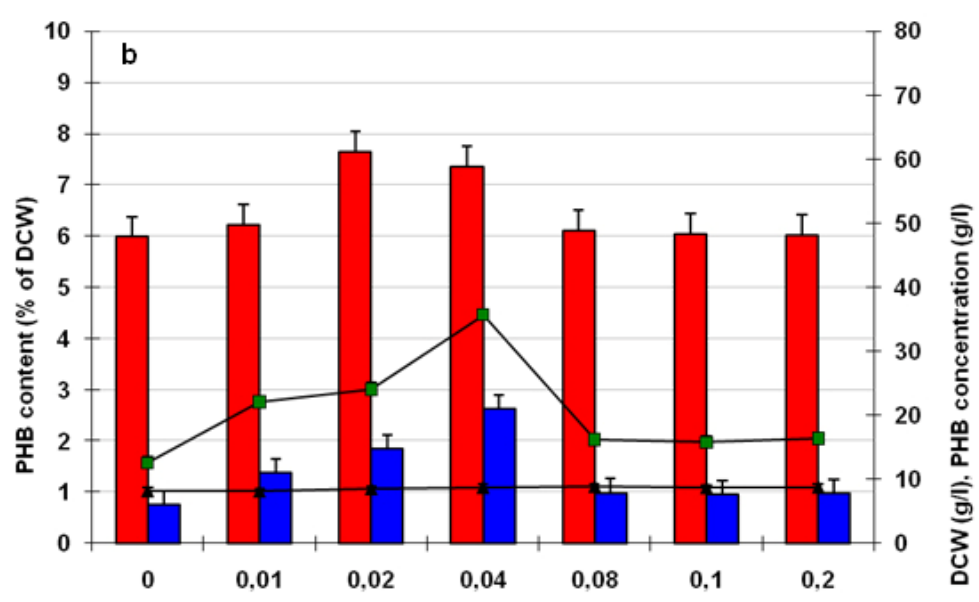

Nitrogen sources and concentrations $(g / 1)$

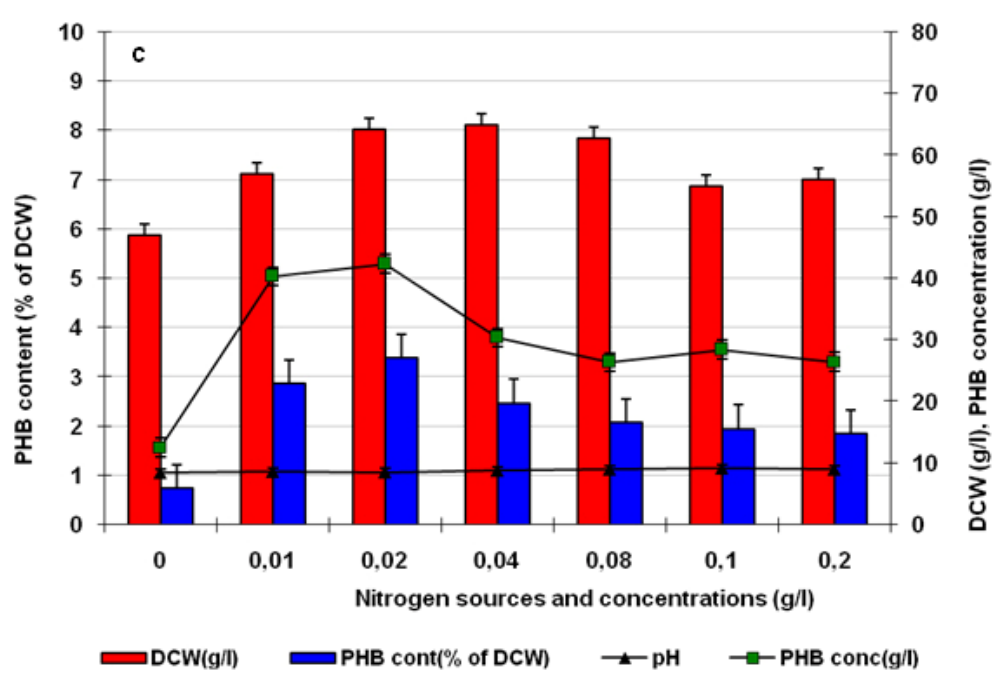

Figure 4. Growth and $\mathrm{PHB}$ accumulation from $48 \mathrm{hrs}$ cultivation of $R$. sphaeroides $\mathrm{N}^{20}$ in $\mathrm{GA}$ medium with (a) ( $\left.\mathrm{NH}_{4}\right)_{2} \mathrm{SO}_{4}$; (b) $\mathrm{NH}_{4} \mathrm{NO}_{3}$; (c) and $\mathrm{NH}_{4} \mathrm{Cl}$ at various concentrations $(0-0.2 \mathrm{~g} / \mathrm{l})$ under aerobic-dark condition at $37^{\circ} \mathrm{C}$ on a shaker $(150 \mathrm{rpm})$. Cell harvested at $60 \mathrm{hrs}$. 

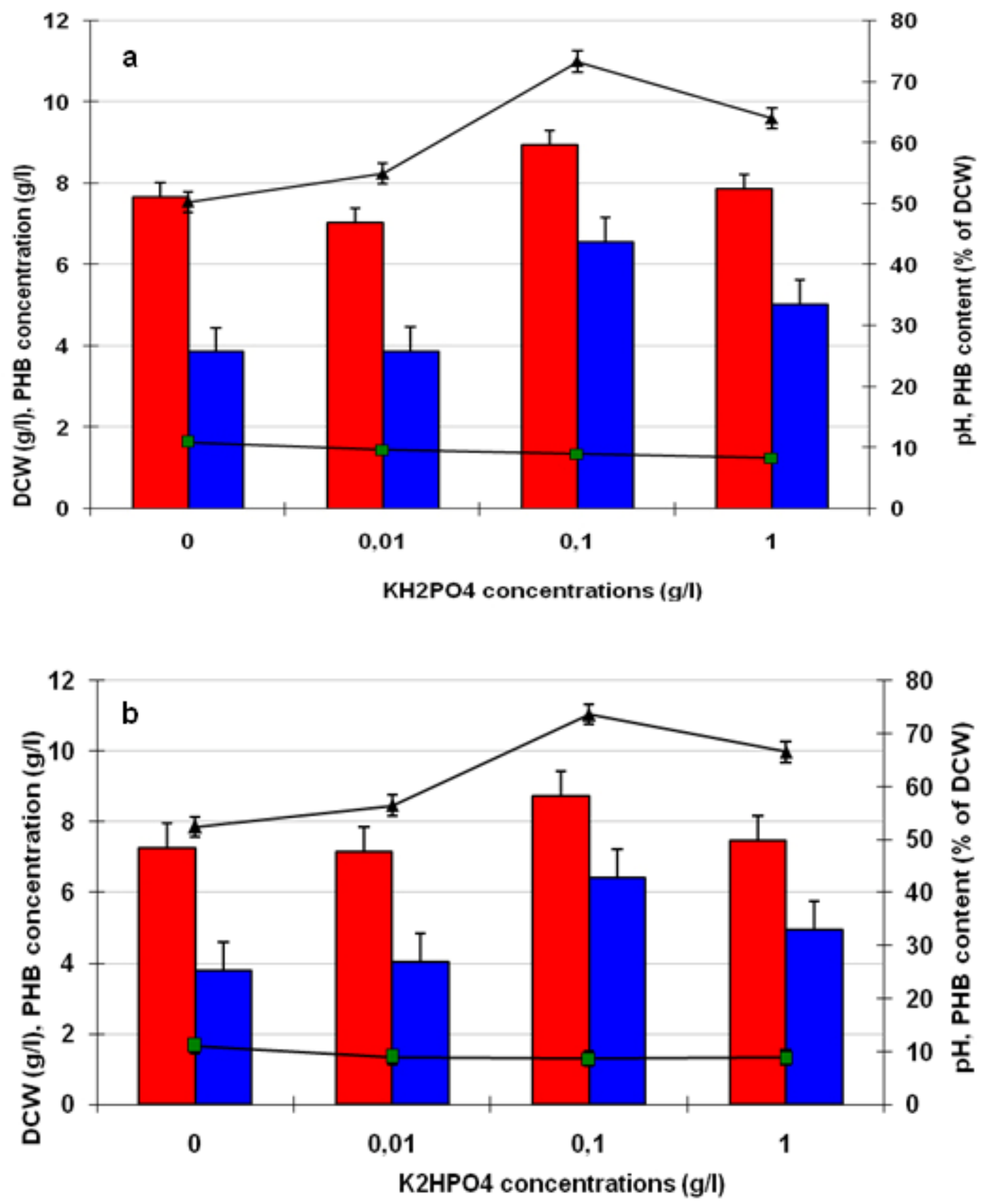

$\square \mathrm{DCW}(\mathrm{g} / \mathrm{l}) \quad \mathrm{PHB} \operatorname{conc}(\mathrm{g} / \mathrm{l}) \quad \longrightarrow \mathrm{PHB} \operatorname{cont}(\%$ of $\mathrm{DCW}) \quad \rightarrow \mathrm{pH}$

Figure 5. Growth and PHB accumulation during cultivation of $R$. sphaeroides $\mathrm{N} 20$ in GA medium with (a) $\mathrm{KH}_{2} \mathrm{PO}_{4}$; $(\mathrm{b})$ and $\mathrm{K}_{2} \mathrm{HPO}_{4}$ at various concentrations $0,0.01,0.1$ and $1 \mathrm{~g} / \mathrm{l}$ under aerobic-dark condition at $37^{\circ} \mathrm{C}$ on shaker $(150 \mathrm{rpm})$ for $60 \mathrm{hrs}$. 


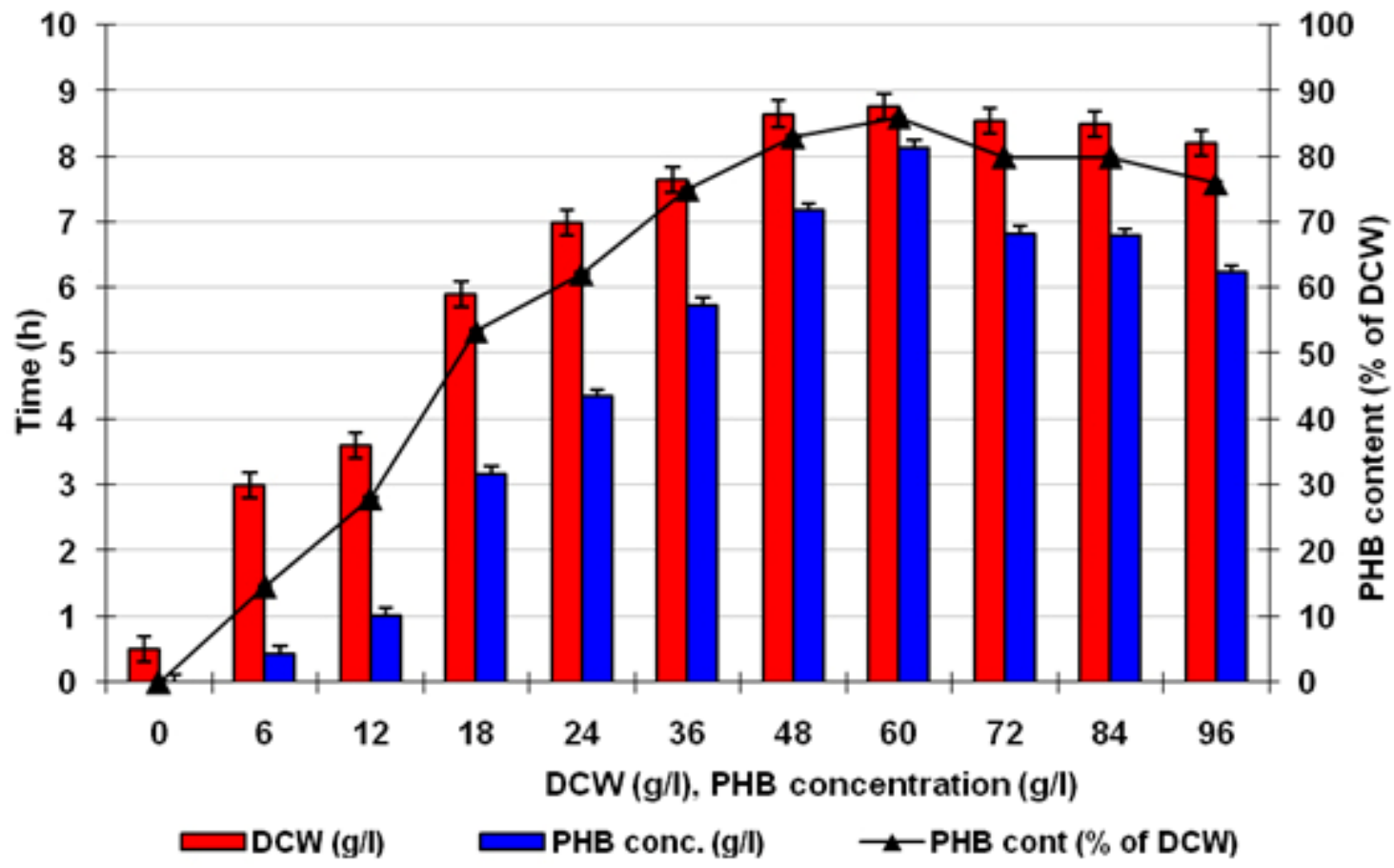

Figure 6. Growth and PHB accumulation of $R$. sphaeroides $\mathrm{N} 20$ on optimal medium contained acetate (carbon source), $4.0 \mathrm{~g} / \mathrm{l}$; $\left(\mathrm{NH}_{4}\right)_{2} \mathrm{SO}_{4}$ (nitrogen source), $0.02 \mathrm{~g} / \mathrm{l} ; \mathrm{KH}_{2} \mathrm{PO}_{4}, 0.1 \mathrm{~g} / \mathrm{l}$ and $\mathrm{K}_{2} \mathrm{HPO}_{4}, 0.1 \mathrm{~g} / \mathrm{l}$; at $37^{\circ} \mathrm{C}$, under controlled agitation and aeration rate at $150 \mathrm{rpm}$ and aeration rate at $1.0 \mathrm{vvm}$, at $\mathrm{pH}(7.0)$. 